\title{
Sustainability assessment of an urban neighbourhood revitalization project in Bogotá, by transposition of a European indicator system to the Colombian context
}

\author{
A. V. Cifuentes, S. Lufkin, M. Riera \& E. Rey \\ Laboratory of Architecture and Sustainable Technologies (LAST), \\ École Polytechnique Fédérale de Lausanne (EPFL), Switzerland
}

\begin{abstract}
With $80 \%$ of its population living in cities, Latin America is one of the most urbanized regions in the planet. Its urban areas are characterized by rapid transformations that entail urban sprawl and its subsequent environmental impacts, social segregation and poverty. Urban revitalization of deteriorated inner-city areas appears as an alternative that seeks to combat these problems and contribute to create more sustainable cities. To support this strategy, it is necessary to develop sustainability assessment methodologies specifically adapted to projects in Latin America. This paper presents the sustainability assessment of the Progresa Fenicia neighbourhood revitalization project, located in Bogotá. The methodology was developed by transposing a European indicator system to the Colombian context. The objective is to support the creation of indicator systems to assess the sustainability of urban revitalization projects at the neighbourhood scale in Colombia. It demonstrates that, to create sustainable neighbourhoods and consequently sustainable cities in a Latin American context, it is not enough to just consider physical and environmental variables related to density, mix land uses and mobility. It is necessary to consider sociocultural, politic and economic issues associated with the guarantee of human rights in the urban context and innovative governance models which prioritize the participation of local community and its empowerment.

Keywords: urban design, urban revitalization, sustainable neighbourhoods, sustainability assessment, indicator system.
\end{abstract}




\section{Introduction}

Giving priority to the revitalization of inner-city areas is a fundamental urban planning principle for many European cities seeking to avoid urban sprawl and its negative consequences [1]. Responding to these new urban challenges, several European countries have already developed different sustainability assessment tools for urban revitalization projects at neighbourhood scale [2-4]. On the other hand, Latin American cities are also facing their boundless growth, and need to take advantage of the potential of underutilized lands [5]. We can affirm that sustainable urban revitalization of inner-city areas is a relevant process in the search for sustainability in European and Latin American cities [6]. However in Latin America, urban planning presents major challenges, mainly regarding social, economic and political stability [7-9]. In the specific case of Colombia, urban planning faces situations of social segregation and economic vulnerability of the population that arrives to the cities displaced by violence [10]. For these reasons it is not enough just to apply European good practices in urban revitalization processes of Latin American contexts. It is necessary to transpose and adapt European methodologies for the assessment and integration of sustainable development into different potential solutions for urban revitalization in Latin America, taking into account the specific challenges of the territory [11].

Trying to fill this gap, the present work aims at transposing European sustainability indicators into a real urban neighbourhood revitalization project in Bogotá. This paper explains the conceptual approach of sustainable development towards a comprehensive and multidimensional sustainability assessment of a neighbourhood located in a Latin American context, as is the case of Colombia. Additionally the methodology of the transposition process is described. Finally, results and main conclusions of the neighbourhood assessment in Bogotá are exposed.

\section{Urban revitalization for sustainable urban development}

The sustainability of cities is not possible if their components (neighbourhoods) do not contribute to their overall sustainability [12]. Therefore, urban revitalization projects focusing on neighbourhood scale must allow cities to concretize their objectives of sustainable development. Indeed, neighbourhood scale appears to be a very appropriate scale for planning. It is the place where inhabitants develop their lives [13], which allows the analysis of physical and human variables. Furthermore, the notion of sustainable neighbourhood is situated exactly at the crossroads between the art of constructing sustainable buildings and the art of managing a sustainable city [14]. By definition, it is based on a global-local approach, which enables the understanding of a variety of aspects at different scales.

To develop a holistic approach towards sustainable development, understanding the objectives of the territory from this global-local approach is essential [15]. It involves knowing the shared objectives between European and Latin American countries, and local objectives of cities in each context. 
Accordingly, to achieve a sustainable urban development, Latin American cities must seek a solution to urban sprawl, but also overcome social segregation, poverty and lack of trust in government [16]. Hence, the notion of sustainable urban revitalization established in this paper, includes not only the regeneration of physical-spatial conditions of the city, but also its human and immaterial conditions [17].

\section{Sustainability assessment at neighbourhood scale}

To develop a sustainable revitalization project at neighbourhood scale, several principles can be found in the literature. Most authors highlight the necessity to use decision-support tools and monitoring assessment indicators to ensure the integration of sustainability principles all along the project process $[1,15,18-20]$.

Mainly in Europe, North America, Australia and China, sustainability assessment tools are used to measure the success of a neighbourhood in approaching sustainable development goals. However, most of the available tools do not involve a holistic approach regarding the simultaneous integration of social, economic and environmental aspects [21]. This can be explained by understanding Sharifi and Murayama's classification [2] that divides neighbourhood assessment tools (NSA) into two groups: "spin-off tools" and "plan-embedded tools". The first category consists of tools derived from building assessment methodologies, which tend to privilege environmental indicators. It is the case of LEEDNeighbourhood Development [22] and BREEAM-Communities [23]. The second category includes tools that contain indicators related to urban plans at neighbourhood scale, i.e. they follow an approach of sustainable city. As a result, these tools, such as $\mathrm{HQE}^{2} \mathrm{R}$ [24], SmèO [25] and SIPRIUS [1], have a better performance supporting the decision-making process of urban revitalization projects.

It can be concluded that plan-embedded tools enable performing a comprehensive sustainability assessment of the neighbourhood, by analysing physical and human variables taking into account the three pillars of sustainability in a transversal way. Furthermore, they allow measuring the success of the neighbourhood responding to the sustainable development goals of a particular context, which is the main objective of the sustainability assessment at neighbourhood scale.

\section{Assessment criteria transposition: from Europe to Latin America}

Considering the characteristics described in the preceding chapter, three "planembedded" tools were analysed in order to select the most appropriate tool for the transposition to a Latin American country. The selected tools share two fundamental characteristics: transversality, i.e. their system of indicators take into account the three pillars of sustainability, and flexibility i.e. their indicators are related to urban land policies which probably are shared with other contexts. 
To make the final selection three criteria were defined (see Table 1): Pragmatic criteria regarding the scale and the type of intervention, Latin American criteria, taking into account the importance of encouraging a new governance which considers the participation of inhabitants in neighbourhood revitalization processes [11], and the Transposition criteria, which means it has to be a tool already transposed to different contexts.

Table 1: Assessment of 3 different plan embedded tools according to 3 defined criteria.

\begin{tabular}{|c|c|c|c|}
\hline Criteria & INDI (HQE $\left.{ }^{2} \mathrm{R}\right)$ [15] & SméO [25] & SIPRIUS [1] \\
\hline $\begin{array}{l}\text { Scale and type } \\
\text { of intervention }\end{array}$ & $\begin{array}{l}\text { Neighbourhood } \\
\text { scale/Renewal } \\
\text { projects }\end{array}$ & $\begin{array}{c}\text { Building and } \\
\text { neighbourhood scales/ } \\
\text { New neighbourhoods, } \\
\text { adaptation for } \\
\text { renewal projects in } \\
\text { process } \\
\end{array}$ & $\begin{array}{c}\text { Neighbourhood } \\
\text { scale/Regeneration } \\
\text { of brownfield sites }\end{array}$ \\
\hline $\begin{array}{c}\text { Governance } \\
\text { and inhabitants }\end{array}$ & $\begin{array}{l}\text { Consultation between } \\
\text { stakeholders is } \\
\text { compulsory }\end{array}$ & $\begin{array}{c}\text { Consultation between } \\
\text { stakeholders is not } \\
\text { compulsory but } \\
\text { possible }\end{array}$ & $\begin{array}{c}\text { Consultation } \\
\text { between stake- } \\
\text { holders is not } \\
\text { compulsory but } \\
\text { possible } \\
\end{array}$ \\
\hline Adaptability & $\begin{array}{l}\text { Already tested on } \\
\text { different European } \\
\text { contexts }\end{array}$ & $\begin{array}{l}\text { Only used in the } \\
\text { Swiss context }\end{array}$ & $\begin{array}{l}\text { Adaptation to other } \\
\text { European contexts } \\
\text { in process } \\
\end{array}$ \\
\hline
\end{tabular}

Based on this analysis, the indicator system called INDI was selected. It responds well to the three defined criteria. INDI is the operational tool of $H Q E^{2} R$, which is a project coordinated by the Centre Scientifique of Technique du bâtiment (CSTB) in France [24]. The operational structure of INDI is based on 4 objectives, 20 themes and 127 indicators. It integrates a global-local approach that takes into account major global goals but also local issues according to the Grenelle Law of the Environment, practices and goals of local actors, and the needs of the context [15].

After the selection of the tool its indicators were evaluated to initiate the transposition which implies three major steps. Firstly, indicators from INDI are selected taking into account the global objectives of Latin America [5] and the local objectives of Bogotá, according to the Exceptional Modification of its Land Management Plan [26]. Secondly, considering the specific needs of the local context, complementary indicators were integrated into the assessment methodology. Finally the selected indicators were adapted to the local context.

\subsection{Choice of indicators}

In order to select from the 127 indicators of INDI, the most coherent ones with the context of Bogotá, 4 criteria were defined (see Table 2). Considering a global- 
local approach they aimed at identifying which of the INDI indicators best represented urban planning challenges in Bogotá, Colombia and Latin America.

Table 2: Criteria for indicators selection.

\begin{tabular}{|c|c|c|}
\hline Criteria & Description & Approach \\
\hline Innovation & $\begin{array}{l}\text { In a globalized context, these indicators stimulate the } \\
\text { development of a polycentric and compact city model [27]. }\end{array}$ & \\
\hline $\begin{array}{l}\text { Human } \\
\text { Rights }\end{array}$ & $\begin{array}{l}\text { Taking into account that Latin America is the most urbanized } \\
\text { and segregated region in the world, human right indicators } \\
\text { are valuable on the way to a more respectful human rights } \\
\text { society. Specifically in the urban revitalization context, the } \\
\text { Right to the City is a main objective }[28,29] \text {. }\end{array}$ & Global \\
\hline Identity & $\begin{array}{l}\text { Indicators that seek to build a positive citizenship culture } \\
{[30] \text {. }}\end{array}$ & Loc \\
\hline Territory & $\begin{array}{l}\text { Indicators related to the public policies of the Exceptional } \\
\text { Modification of the Land Management Plan of Bogotá [26]. }\end{array}$ & LOcal \\
\hline
\end{tabular}

These criteria allowed the selection of 33 indicators ( $26 \%$ of INDI), meeting the global and local needs of the territory. Public policies of the Land Management Plan of Bogotá were taken into account in a transversal way so each indicator is related to a public policy of the local context.

\subsection{Integration of specific indicators}

The local context faces specific problems which are not taken into account by the INDI system. To achieve a comprehensive evaluation of an urban revitalization project in Bogotá, it is necessary to incorporate new indicators that respond to local issues. Consequently, the assessment methodology is enriched with 2 new themes which are described below.

\subsubsection{Re-densification}

Bogotá is considered one of the densest cities in the world [31], its land management policies do not seek a densification of the city but a re-densification [32], which makes necessary to address this issue not only in human terms (as it is studied in INDI, item 5 [15]) but also in physical spatial terms. Consequently occupation and land use indicators from the assessment tool SméO [25] are incorporated into the assessment methodology. The amount of occupied floor and the built area are evaluated in order to preserve green areas and to generate public space.

\subsubsection{Accessibility to basic urban services}

One of the biggest problems of Bogotá, as well as of most Latin American cities, is urban informality, which means people living without basic urban services [5]. As it is a very specific problem in developing contexts, it is not taken into account by INDI, neither by the other analyzed assessment tools. Therefore, a new indicator that assess in a qualitative way the accessibility of the neighborhood to water, sanitation and electricity is created. 


\subsection{Transposition of indicators}

The result of the above-described process is a list of 35 indicators which aim to assess, from a multidimensional perspective, the success of a neighbourhood in meeting sustainable development challenges in the capital of Colombia. In this perspective, the transposition process must go beyond the mere selection of indicators, and their structure has to be studied for a better contextualization. In conclusion $34 \%$ of the indicators remained as described in INDI (I) while $60 \%$ were modified in their structure (M) which means that the measuring method and the rating system were adapted according to laws, regulations, methods and trends of urban revitalization in Bogotá. Lastly $6 \%$ correspond to new indicators.

Table 3: List of indicators meeting urban land policies of Bogotá.

\begin{tabular}{|c|c|c|c|c|c|c|}
\hline \multicolumn{2}{|c|}{$\begin{array}{l}\text { Urban Land Policies } \\
\text { MEPOT [26] }\end{array}$} & \multicolumn{2}{|r|}{ Indicators } & \multirow{2}{*}{$\frac{\mathrm{I}}{\mathrm{x}}$} & \multirow[t]{2}{*}{$\mathbf{M}$} & \multirow[t]{2}{*}{$\mathbf{N}$} \\
\hline \multirow{5}{*}{1} & \multirow{5}{*}{$\begin{array}{l}\text { Environmental } \\
\text { Sustainability }\end{array}$} & 1 & Knowledge and respect for ecological continuity & & & \\
\hline & & 2 & Biotope coefficient & & $\mathrm{x}$ & \\
\hline & & 3 & Tree coverage & & $\mathrm{x}$ & \\
\hline & & 4 & Rainwater management & & $\mathrm{x}$ & \\
\hline & & 5 & Outdoor air quality & & $\mathrm{x}$ & \\
\hline \multirow{5}{*}{2} & \multirow{5}{*}{$\begin{array}{l}\text { Risk Management } \\
\text { and Adaptation to } \\
\text { Climate Change }\end{array}$} & 6 & Consideration of climate change (natural risks) & $\mathrm{x}$ & & \\
\hline & & \begin{tabular}{|l|}
7 \\
\end{tabular} & Building orientation and optimization of free solar gains & & $\mathrm{x}$ & \\
\hline & & 8 & $\begin{array}{l}\text { Energy efficiency of residential buildings (new and } \\
\text { existing) }\end{array}$ & & $\mathrm{x}$ & \\
\hline & & 9 & Reduction of artificial lighting needs & & $\mathrm{x}$ & \\
\hline & & 10 & Illumination level of public lighting & & $\mathrm{x}$ & \\
\hline \multirow{4}{*}{3} & \multirow{4}{*}{ Urban Habitat } & 11 & Mix land uses & $\mathrm{x}$ & & \\
\hline & & 12 & Quality of residential buildings and dwellings & & $\mathrm{x}$ & \\
\hline & & 13 & Social mix: social rental housing & & $\mathrm{x}$ & \\
\hline & & 14 & Safety of people and property & & $\mathrm{x}$ & \\
\hline \multirow{4}{*}{4} & \multirow{4}{*}{$\begin{array}{l}\text { Differential } \\
\text { Approach }\end{array}$} & 15 & Education in civic culture & $\mathrm{x}$ & & \\
\hline & & 16 & Transversality of the project management structure & $\mathrm{x}$ & & \\
\hline & & 17 & Sustainable Development project charter & $\mathrm{x}$ & & \\
\hline & & 18 & Participation of residents and users & $\mathrm{x}$ & & \\
\hline \multirow{4}{*}{5} & \multirow{4}{*}{ Productivity } & 19 & Use of local materials & & $\mathrm{x}$ & \\
\hline & & 20 & Actions for sustainable employments & & $\mathrm{x}$ & \\
\hline & & 21 & Proficiency of project's economics & $\mathrm{x}$ & & \\
\hline & & 22 & Assessment of procedures & $\mathrm{x}$ & & \\
\hline \multirow{2}{*}{6} & \multirow{2}{*}{ Revitalization } & 23 & Net human density & & $\mathrm{x}$ & \\
\hline & & 24 & Occupation and land use & & & $\mathrm{x}$ \\
\hline 7 & Heritage & 25 & Preservation and promotion of heritage & $\mathrm{x}$ & & \\
\hline \multirow{4}{*}{8} & \multirow{4}{*}{ Mobility } & 26 & Access to structuring transport & & $\mathrm{x}$ & \\
\hline & & 27 & Bicycle slots in buildings & & $\mathrm{x}$ & \\
\hline & & 28 & Bike paths & & $\mathrm{x}$ & \\
\hline & & 29 & Quality of pedestrian paths & $\mathrm{x}$ & & \\
\hline \multirow{3}{*}{9} & \multirow{3}{*}{ Public Services } & 30 & Accessibility to basic urban services & & & $\mathrm{x}$ \\
\hline & & 31 & Management of construction waste & & $\mathrm{x}$ & \\
\hline & & 32 & Household waste management & $\mathrm{x}$ & & \\
\hline \multirow{2}{*}{10} & \multirow{2}{*}{ Public Space } & 33 & Surface area of public green spaces & & $\mathrm{x}$ & \\
\hline & & 34 & Enhance the quality of the urban form & & $\mathrm{x}$ & \\
\hline 11 & Urban Equipment & 35 & Proximity and access to urban equipment & & $\mathrm{x}$ & \\
\hline
\end{tabular}




\section{Sustainability assessment of Progresa Fenicia project}

Having completed the indicators transposition process, the sustainability assessment of the neighbourhood revitalization project in Bogota is possible. This chapter presents the selection of the case study, and the evaluation of the most relevant indicators.

\subsection{Choice of the neighbourhood}

The criteria described in Table 4 are defined in order to select a revitalization project having an impact on the achievement of the sustainable development goals of the city of Bogotá. In addition, the case study should include not only physical and environmental issues but also socio-cultural, political and economic ones. Hence, the project can be evaluated following a multidimensional approach, as the one here developed.

Table 4: Criteria defined in order to choose the neighbourhood revitalization project.

\begin{tabular}{|l|l|l|}
\hline Criteria & Theme & Description \\
\hline Innovation & $\begin{array}{l}\text { Density, mobility, } \\
\text { mix land uses }\end{array}$ & $\begin{array}{l}\text { Have a global urban logic in which the } \\
\text { densification, mobility and mix land uses are } \\
\text { privileged. The concept of compact city [27]. }\end{array}$ \\
\hline $\begin{array}{l}\text { Human } \\
\text { Rights }\end{array}$ & $\begin{array}{l}\text { The Right to the } \\
\text { City }\end{array}$ & $\begin{array}{l}\text { Take into account the Right to the City [28, 29] of } \\
\text { pre-existing and future inhabitants. }\end{array}$ \\
\hline $\begin{array}{l}\text { New } \\
\text { Governance }\end{array}$ & $\begin{array}{l}\text { Common sense } \\
\text { and participation } \\
\text { interests of the promoters of the project. The idea } \\
\text { is to build a shared story [34] which means that } \\
\text { participation of inhabitants is necessary from the } \\
\text { beginning. }\end{array}$ \\
\hline $\begin{array}{l}\text { Pragmatic } \\
\text { conditions }\end{array}$ & Project size & $\begin{array}{l}\text { An intermediate size (5-10 ha) that enables a } \\
\text { complete analysis of physical and human } \\
\text { variables. }\end{array}$ \\
\cline { 2 - 3 } & $\begin{array}{l}\text { Information } \\
\text { accessibility }\end{array}$ & $\begin{array}{l}\text { A revitalization project published on the website } \\
\text { of the District Planning Secretariat of Bogotá [35]. }\end{array}$ \\
\hline
\end{tabular}

The modification of the Land Management Plan of Bogotá proposes an approach of urban development in which the re-densification, mobility and mix land uses are key strategies for sustainable development [26]. Within this focus 21 urban revitalization projects were identified [32] of which only one fulfilled all the defined criteria described in Table 4 . This is the urban revitalization project called "Progresa Fenicia" [33].

\subsection{Sustainability assessment of the revitalization project "Progresa Fenicia"}

Progresa Fenicia is an ambitious urban neighbourhood revitalization project, located at the center of Bogotá and led by the University of Los Andes. Its main 
challenge is to reduce social segregation avoiding gentrification, being the only urban process with these characteristics in Bogotá. The project was already approved by the District Planning Secretary and this year it is expected to initiate the construction of the first phase.

Four representative indicators were selected to illustrate synthetically the sustainability assessment of Progresa Fenicia neighbourhood (see Table 5) and also to show the differentiating features of the project. They are related to 4 public policies of the Land Management Plan of Bogotá [26], and classified according to the selection criteria of indicators in Table 2 (Innovation (In), Human Rights (Hr), Identity (Id), New Governance (Ng)), the multidimensionality or three pillars of sustainability (Environmental (En), Social (So) and Economic (Ec)), and the type of indicator (quantitative (Qn) or qualitative (Q1)).

Table 5: Selection of 4 representative indicators illustrating the assessment process.

\begin{tabular}{|c|c|c|c|c|c|c|c|c|c|c|c|c|}
\hline & \multirow[b]{2}{*}{ Public Policies } & & \multirow[b]{2}{*}{ Indicator } & \multicolumn{4}{|c|}{ Criteria } & \multicolumn{3}{|c|}{3 Pillars } & \multicolumn{2}{|c|}{ Type } \\
\hline & & & & In & $\mathrm{Hr}$ & $\mathrm{Id}$ & $\mathrm{Ng}$ & En & So & Ec & Qn & $\mathrm{Q1}$ \\
\hline $\begin{array}{l}\overline{0} \\
\frac{0}{0} \\
0\end{array}$ & Re-densification & 1 & $\begin{array}{l}\text { Occupation and } \\
\text { land use }\end{array}$ & $\mathrm{X}$ & & & & $\mathrm{X}$ & & & $\mathrm{x}$ & \\
\hline \multirow{2}{*}{ ت్త్ర } & Productivity & 2 & $\begin{array}{l}\text { Actions for } \\
\text { sustainable } \\
\text { employments }\end{array}$ & & $\mathrm{X}$ & & & & & $\mathrm{X}$ & & $\mathrm{X}$ \\
\hline & Urban Habitat & 3 & \begin{tabular}{|l|} 
Social mix: Social \\
rental housing
\end{tabular} & & $\mathrm{X}$ & & & & $\mathrm{X}$ & & $\mathrm{X}$ & \\
\hline 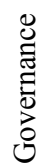 & $\begin{array}{l}\text { Differential } \\
\text { Approach }\end{array}$ & 4 & $\begin{array}{l}\text { Participation of } \\
\text { residents and users }\end{array}$ & & & $\mathrm{X}$ & $\mathrm{X}$ & & $\mathrm{X}$ & & & $\mathrm{X}$ \\
\hline
\end{tabular}

Indicators related to re-densification, productivity, urban habitat and differential approach are described below. A scale from 0 to 5 allows placing the results of the assessment, where 0 is a not considered variable, 3 is an acceptable practice and 5 is the best practice.

\subsubsection{Occupation and land use (Innovation)}

The revitalization project seeks, on the one hand, to reduce the lot coverage from 0.47 (actual scenario) to 0.25 , this in order to offer a more open urban structure with a wide range of public space. As a result public space is almost doubled, from 3.8 ha in the actual scenario, to $6.2 \mathrm{ha}$ in the revitalization scenario as shown in Figure 1. On the other hand the floor area ratio is increased from 1.41 to 2.96, which complies with legal land regulations regarding re-densification. As a result a rating of 5 is given to this indicator. 

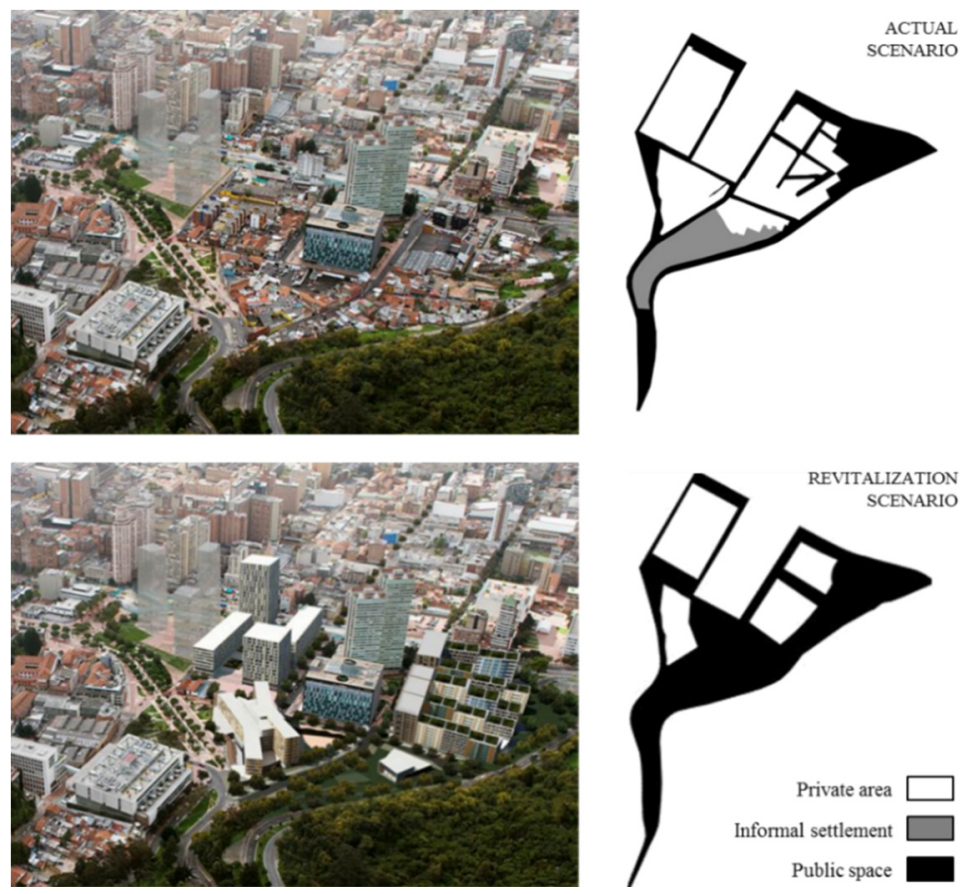

Figure 1: Re-densification of Progresa Fenicia neighbourhood and reconfiguration of its public space [33].

\subsubsection{Actions for sustainable employments (Human Rights)}

Informal employment is a recurrent feature of neighbourhoods in developing contexts [9]. According to the study of social and economic dynamics of the neighbourhood [33], one of the main challenges is to encourage the creation of formal jobs. For that purpose two training programs were created: the program "Training for Work" addressed to young people between 15 and 25 years old, and the program "Business start-up Fenicia" addressed to small entrepreneurs in the sector. The rating for this indicator is also 5 as the ultimate goal is to combat informality by empowering inhabitants with a job that gives them financial stability and self-confidence.

\subsubsection{Social mix: social rental housing (Human Rights)}

Social mix in Latin America is a strategy against segregation [34]. In Progresa Fenicia more than $20 \%$ of the dwellings will be destined for actual residents of the neighbourhood who are currently living in precarious conditions, and also for future residents with the same economic difficulties. The aim is to ensure the Right to the City of vulnerable people by assuring them dignified housing in an innercity area where they will have accessibility to different urban services. The rating for this indicator is 4, taking into account that social mix in the city of Bogotá faces the obstacle of the socio-economic stratification system which limits social mix possibilities. 


\subsubsection{Participation of residents and users (Identity and New Governance)}

Since the beginning of the design process the model of "participatory urban design" has been implemented. It involves the development of 4 types of workshops where residents are participating [36]. This model allows knowing the desires, interests, fears and expectations of pre-existing and future inhabitants in relation to the transformation of the neighbourhood. All this information is being considered in the design criteria and in the project development, for this reason a rating of 5 is given to this indicator.

\subsection{Results}

The sustainability assessment allows measuring the success of the neighbourhood revitalization project in approaching sustainable development goals of the city of Bogotá. The radar chart (Figure 2) summarizes the assessment and results of the 35 indicators listed in Table 3. It also highlights the strengths and weaknesses of the revitalization project.

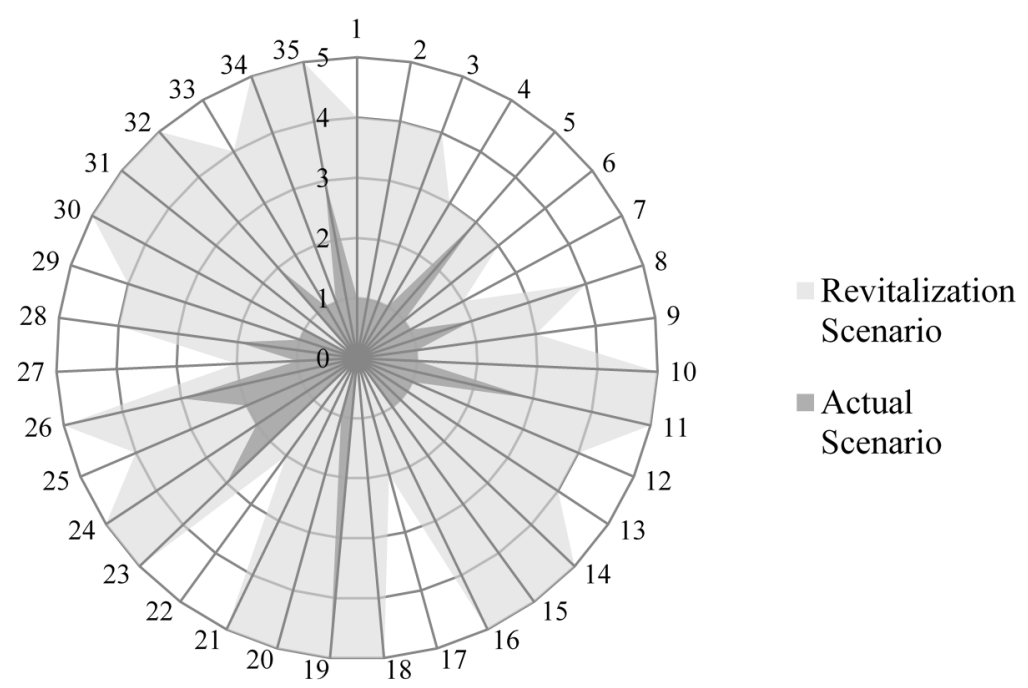

Figure 2: Synthesis of results regarding 35 indicators.

Progresa Fenicia responds well to indicators related to mix land uses (11), mobility (26), and density $(23,24)$, which means that the revitalization project follows the concept of a polycentric compact city model. Regarding the guarantee of human rights in an urban context [29], it was demonstrated that Progresa Fenicia guarantees the right to water and to access and supply of domestic and urban public services $(30,32$, and 35$)$, the right to work (20) and the right to housing $(12,13)$. Concerning the right to a healthy and sustainable environment, a good performance was observed for the following indicators: knowledge and respect for ecological continuity (1), biotope coefficient (2) and surface area of public green spaces (33). Finally, indicators related to a new governance model that stimulates 
the transversality of the project management (16), the participation of residents and users (18) and the empowerment of citizens (15) reach the best performance.

The weaknesses of the revitalization project concern topics related to environmental sustainability such as rainwater management (4), which can be improved by the project, and outdoor air quality (5). The latter issue related to the context where the neighbourhood is located, which makes it harder to improve. A low performance was also observed for the optimization of free solar gains indicator (7), which can be explained by the fact that bioclimatic urbanism is a very recent concept in Bogotá.

Two indicators related to procedures also obtained low scores. They concern the introduction of a sustainable development charter (17) and the assessment of procedures (22) issues that have not been taken into account yet and that may help to guide the project towards better performances.

\section{Discussion}

The indicators choice according to the criteria of innovation, human rights and new governance, and their transposition to the Colombian context, allowed the evaluation of $35 \mathrm{key}$ issues for achieving the objectives of sustainable development of Bogotá. The assessment of Progresa Fenicia revitalization project teaches that, although a comprehensive approach of the three pillars of sustainability is necessary, social and economic indicators related to human rights and new governance are those that require more effort and, at the same time, those that will really support the achievement of the major goals of Latin America concerning social segregation, poverty and lack of trust in government. Accordingly, it is not enough to just consider physical and environmental variables in neighbourhood revitalization projects of Colombia.

\section{Conclusion}

It is the first time that a European indicator system, for urban neighbourhood revitalization projects, is transposed to a Latin American context. This exercise required a holistic view of sustainable development and also a global-local approach which helped to structure not only the transposition process but also the sustainability assessment methodology. The result is the sustainability assessment of a neighbourhood revitalization project in Bogotá, which provides a comprehensive and multidimensional understanding of the planning decisions taken at the neighbourhood scale, and their impacts on the sustainable development goals of the city, the country and the region. Therefore, this work is a foundation stone towards sustainable revitalization in Latin America, and opens the research towards the creation of a sustainability assessment indicators system for Colombian urban contexts, which may truly support the decision-making process during the development of different neighbourhood revitalization processes. 


\section{References}

[1] Rey, E., Régénération des friches urbaines et développement durable: vers une évaluation intégrée à la dynamique du projet, Louvain-La-Neuve: Presses Universitaires, 2012.

[2] Sharifi, A., \& Murayama, A., A critical review of seven selected neighborhood sustainability assessment tools. Environmental Impact Assessment Review, 38, pp. 73-87, 2013.

[3] Gil, J., \& Pinto Duarte, JP., Tools for evaluating the sustainability of urban design: a review, Proceedings of the ICE - Urban Design and Planning, Volume 166, Issue 6, pp. 311-325, 2013.

[4] Karol, E., \& Brunner, J., Tools for Measuring Progress towards Sustainable Neighborhood Environments, Sustainability 2009, 1, pp. 612-627.

[5] Programa de las Naciones Unidas para los Asentamientos Humanos (ONUHábitat). Estado de las ciudades de América Latina y el Caribe 2012, Publicación ONU: Nairobi, Kenya, 2012.

[6] United Nations Human Settlements Programme (UN-Habitat). State of the world's cities 2012/2013, UN Publication: Nairobi, Kenya, 2012.

[7] Cohen, B., Urbanization in developing countries: Current trends, future projections, and key challenges for sustainability, Technology in Society, 28, pp. 63-80, 2006.

[8] Bolay, J.C., Pedrazzini, Y., \& Rabinovich, A., Quel sens au “développement durable" dans l'urbanisation du tiers monde?, Les annales de la recherche urbaine, 86, pp. 77-84, 2000.

[9] Comisión Económica para América Latina y el Caribe (CEPAL), Gestión urbana para el desarrollo sostenible en América Latina y el Caribe, Publicación ONU: Santiago de Chile, 2003.

[10] Bello, M., El desplazamiento forzado en Colombia: acumulación de capital y exclusión social. Aportes Andinos No 7. Quito: Universidad Andina Simón Bolívar, Sede Ecuador; Programa Andino de Derechos Humanos, 8p, 2003.

[11] URB-AL III, Desarrollo urbano sostenible en Latinoamérica, Parte 1: Estudio sobre las condiciones generales para la revitalización de áreas urbanas en México, Colombia, Ecuador, Brasil y Chile, Imprenta Mariscal, Quito, Ecuador, 2011.

[12] Choguill C.L., Developing sustainable neighborhoods. Habitat International, 32, pp. 41-48, 2008.

[13] Charlot-Valdieu C., \& Outrequin P., Intégration du développement durable dans les projets d'aménagement et de renouvellement urbain. Actes de la conférence européenne des 2 et 3 février 2004, La Calade: Cannes, 2004

[14] Lefèvre P., \& Sabard M., Les écoquartiers. L'avenir de la ville durable. Apogée, 261p, Rennes, 2009.

[15] Charlot-Valdieu C., \& Outrequin P., Concevoir et évaluer un projet d'ecoquartier avec le référentiel INDI. Édition Le Moniteur, París, 2012. 
[16] URB-AL III, Desarrollo urbano sostenible en Latinoamérica, Parte 2: Lecciones aprendidas en proyectos piloto de la revitalización de áreas urbanas en México, Colombia, Ecuador y Brasil, Edición 500, 2012.

[17] Gehl, J., Cities for people, Island Press: Washington DC, 2010.

[18] Luederitz, C., Lang DJ., \& Von Wehrden, D., A systematic review of guiding principles for sustainable urban neighborhood development, Landscape and Urban Planning, 118, pp. 40-52, 2013.

[19] Riera Pérez M.G. \& Rey E., A multi-criteria approach to compare urban renewal scenarios for an existing neighborhood. Case study in Lausanne (Switzerland). Building and Environment 65, pp. 58-70, 2013.

[20] Laprise, M. Intégration des enjeux de la durabilité aux projets de régénération de friches urbaines: Du référentiel théorique à l'outil de monitoring opérationnel. Thesis in progress within the Laboratory of Sustainable Architecture Technologies (LAST), EPFL, 2014.

[21] Charlot-Valdieu C, Outrequin P. Ecoquartier: Mode D'emploi. 1st ed. Paris: Eyrolles, 2009.

[22] LEED, for Neighborhood Development. The US Green Building Council, Inc., 2011.

[23] BREEAM, Homepage of BREEAM, Website, http://www.breeam.org/

[24] SUDEN, La démarche $\mathrm{HQE}^{2} \mathrm{R}$ de conduite de projet urbain intégrant le développement durable, La Calade, 2004.

[25] Roulet Y, Liman U. Jalons6. SméO Fil rouge pour la construction durable. Lausanne: Etat de Vaud, Ville de Lausanne, 2009.

[26] Alcaldía Mayor de Bogotá, Decreto 364 de 2013, Modificación Excepcional de Normas Urbanísticas del Plan de Ordenamiento Territorial (MEPOT), Bogotá, 2013.

[27] Rogers, R. \& Gumuchdjian, P., Cities for a small planet, Icon Editions. Boulder, Colo.: Westview, 1998.

[28] Harvey D. The Right to the City, New Left Review 53, pp. 23-40, 2008.

[29] UNESCO, World Charter on the Right to the City. World Urban Forum. Barcelona, 2004.

[30] Mockus A. Bogotá: ¿Cohesión social vía innovación? Cultura ciudadana y espacio público: motivaciones y regulaciones, Presentación en el Encuentro de Representantes de Gobiernos Subnacionales de la Unión Europea y América latina. Lecciones y Experiencias del Programa URB-AL, Rosario, Argentina 3-5 de julio, 2007.

[31] Secretaría Distrital de Planeación, Bogotá ciudad de estadísticas. Boletín №22: Densidades Urbanas. Bogotá, 2011.

[32] Cámara de Comercio de Bogotá, Los retos de la revitalización urbana. El centro ampliado. Primer Simposio Internacional de Renovación Urbana, Bogotá, 2012.

[33] Universidad de los Andes, Ajustes a la Formulación, Plan Parcial Triángulo de Fenicia, Bogotá, 2014.

[34] Cifuentes Quin, C.A, Tixier, N., An Inside Look at Bogotá's urban renewal from broad urban stories to everyday tales, 6th Conference of the International Forum on Urbanism (IFoU). pp. 1-11, Barcelona, 2012. 
92 The Sustainable City X

[35] Secretaría Distrital de Planeación (SDP). Planes Parciales de Renovación Urbana, Website, Bogotá DC http://www.sdp.gov.co/

[36] Universidad de los Andes, Visiones Futuras Fenicia. Talleres de composición participativa, Bogotá, 2014. 